\title{
Polymyalgia rheumatica and temporal arteritis: a retrospective analysis of prognostic features and different corticosteroid regimens (11 year survey of 210 patients)
}

\author{
G DELECOEUILleRiE, P JOLY, A COHEN DE LARA, AND J B PAOLAGGI
}

From the Department of Rheumatology, Ambroise Pare Hospital, 9 Av Ch de Gaulle, 92104 Boulogne Cedex, France

SUMmARY The treatment of polymyalgia rheumatica (PMR) and temporal arteritis (TA) is still controversial. To assess the influence on the course of these diseases of the clinical symptoms at initial presentation and of the starting dosage of corticosteroid (CS) treatment the data for 210 patients, who were diagnosed as having PMR or TA from 1976 to 1986 and were followed up closely, were reviewed. One hundred and thirty two patients were diagnosed as having "clinically pure' PMR; prednisone starting doses of over $15 \mathrm{mg}$ daily provided more CS related adverse effects without any advantage. The mean duration of treatment was 25.7 months. Nine patients later developed symptoms of TA, and there were no predictive features for this. None experienced visual or neurological complications. Seventy eight patients were diagnosed as having clinical TA. Twenty five patients treated with low starting doses of prednisone, ranging from 10 to $20 \mathrm{mg} / \mathrm{d}$ (mean $16.2 \mathrm{mg} / \mathrm{d}$ ), developed less CS related adverse effects and did not have more visual or neurological complications than 53 patients treated with higher doses. The mean duration of treatment was 30.9 months. Fifteen patients experienced visual or neurological complications and men (10/30) developed these complications more frequently than women $(5 / 48)(\mathrm{p}<0 \cdot 02)$. These results suggest that $(a)$ clinically pure PMR is a benign disease requiring low doses of CS treatment; $(b)$ low doses of CS seem an adequate treatment for most cases of $\mathrm{TA} ;(c)$ a worse prognosis seems attached to the male sex in TA.

Key words: giant cell arteritis, temporal artery biopsy.

Temporal arteritis (TA) and polymyalgia rheumatica (PMR) were first described as two distinct diseases. It then appeared that TA and PMR frequently occurred together and that histological evidence of giant cell arteritis was found in up to $40 \%$ of patients with clinically pure PMR. There is still controversy about the relation between TA and PMR and about the treatment they require. Some authors consider PMR and TA as two expressions of a single disease and recommend treating all patients with high doses of corticosteroids (CS). ${ }^{1-3}$ Other authors divide the patients according to the results

Accepted for publication 19 February 1988.

Correspondence to Dr G Delecoeuillerie. Department of Rheumatology. Ambroise Pare Hospital. 9 Av Ch de Gaulle. 92104 Boulogne Cedex. France. of temporal artery biopsy, considering patients with clinically pure PMR and histological evidence of giant cell arteritis from temporal artery biopsy to be patients with $\mathrm{TA}^{+5}$ Other authors maintain the distinction between PMR and TA according to the clinical symptoms at initial presentation regardless of temporal artery biopsy findings, ${ }^{67}$ clinically pure PMR being a benign disease which does not require high doses of CS. A few authors even suggested that low doses of CS were adequate treatment for most cases of TA. ${ }^{68}$

Overtreating elderly people with CS if not necessary may be damaging. To find out whether high doses of CS are useful for the treatment of TA and PMR the influence on the course of these diseases of the clinical symptoms at initial presentation and of 
various dosages of CS treatment were retrospectively studied in 210 patients.

\section{Patients and methods}

The data for all the patients who were diagnosed as having PMR or TA in our rheumatology department from January 1976 to December 1986 and who were closely followed up (until the last event relating to their disease) were retrospectively reviewed. A detailed description of the initial clinical symptoms was always available. The patients were divided into two groups according to their clinical symptoms at initial presentation, regardless of temporal artery biopsy findings.

\section{GROU P A}

Group A consisted of the patients with clinically pure PMR. The following features were all required for inclusion in group A: (a) pain and morning stiffness affecting the shoulder or pelvic girdle, $(b)$ age over 50 years, $(c)$ increased erythrocyte sedimentation rate (ESR) over $30 \mathrm{~mm} / 1 \mathrm{st} \mathrm{h}$; normal ESR was not a criterion of exclusion when orosomucoid and haptoglobin were markedly increased, ${ }^{9}$ (d) absence of clinical, radiological, and laboratory evidence of rheumatoid arthritis, systemic lupus erythematosus, or muscle disease at initial presentation and at follow up examination, (e) prompt response to CS treatment.

\section{GROU P B}

This group consisted of patients with clinical TA and was initially divided into two subgroups: pure TA and mixed TA/PMR. As no significant differences were observed between these two subgroups (see below), all patients with TA (pure or associated with PMR) were put into a single TA group. Four of the following seven features were required for inclusion in the TA group: $(a)$ recent temporal or occipital pain or scalp tenderness, $(b)$ jaw claudication, $(c)$ tender, swollen temporal artery, thickening or diminished temporal pulse, $(d)$ transient or sudden loss of vision, ophthalmoplegia or blurred vision, (e) general symptoms: fever, weight loss, anorexia, $(f)$ over 50 years of age, $(g)$ increased ESR over $30 \mathrm{~mm} / 1 \mathrm{st} h$ or markedly increased orosomucoid and haptoglobin.

A temporal artery biopsy was performed on all patients with TA and on some patients with PMR. Histological evidence of giant cell arteritis was established (positive biopsy) when a temporal artery biopsy showed two or three of the following criteria: (a) mononuclear cell infiltate, $(b)$ fragmentation of the internal elastic membrane, $(c)$ presence of giant cells. The results of the biopsy did not influence the classification of our patients: a patient with clinical symptoms of pure PMR, even with a positive $\frac{\sigma}{\omega}$ biopsy, was included in group $\mathrm{A}$ and a patient with negative biopsy but clinical evidence of TA wase? included in group B.

For all patients laboratory investigations included흘 ESR, haemoglobin, white cell count, alkaline phos $-\frac{\bar{c}}{\frac{5}{6}}$ phatase, plasma proteins (haptoglobin, orosomu- $-\frac{\mathbb{D}}{\Omega}$ coid, serum immunoglobulins), creatine kinase rheumatoid factor, and antinuclear antibodies $\vec{P}$ Chest and pelvis radiographs were checked. AIP patients were promptly treated with CS. The alloca $\vec{\omega}$ tion of the starting dosage was not randomised. No criterion determined the choice of the starting dosage, except when visual symptoms existed ats initial presentation (all the patients with initial visua ${ }_{0}$ symptoms were treated with at least $1 \mathrm{mg} / \mathrm{kg} / \mathrm{d}$ of prednisone). The patients were further divided intœ subgroups as follows according to their starting dose of prednisone: group $\mathrm{A}$ - subgroup 1 consisted of patients who received $7-12 \mathrm{mg} / \mathrm{d}$ of prednisone $\infty 5$ subgroup 2: $15-30 \mathrm{mg} / \mathrm{d}$ of prednisone; group B-subgroup I: $10-20 \mathrm{mg} / \mathrm{d}$ of prednisone, subgroup II: over 20 and under $60 \mathrm{mg} / \mathrm{d}$ of prednisone subgroup III: $60-90 \mathrm{mg} / \mathrm{d}$ of prednisone. The starting dose was considered to be effective whro the clinical symptoms disappeared within 48 hour 90 and the ESR promptly decreased. When ineffect the starting dose was promptly increased (in this case the patients remained in the subgroup deter mined by the initial starting dosage). CS dosage wa\& then adjusted to the minimal level sufficient t 8 eliminate the clinical symptoms and to keep the ESR under $30 \mathrm{~mm} / 1 \mathrm{st} \mathrm{h}$.

Remission was defined as the prolonged absence of symptoms, allowing a withdrawal of CS treatment. after progressive decrease of its dosage. Relapse waฐ defined by the recurrence of clinical symptoms afte treatment withdrawal, requiring its reinstitution. $\frac{\dot{\sigma}}{3}$

Statistical significance of differences between groups of patients was determined with a two taile $\Phi$ Student's $t$ test or variance analysis and $\chi^{2}$ analysis with Yates's correction when necessary.

\section{Results}

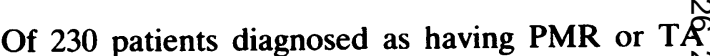
during the study period, 20 were lost to follow ups the study population then consisted of 210 patients, 71 men and 139 women.

A preliminary study showed no significant differo ence on follow up between 38 patients with pure $T$. and 40 patients with mixed TA/PMR at initiat presentation (Table 1).

One hundred and thirty two patients, 41 men and 91 women, were diagnosed as having pure PMR 
(group A). In this group 98 patients were given a starting dose of prednisone ranging from 7 to 12 $\mathrm{mg} / \mathrm{d}$ (mean 10.2) (subgroup 1) and 34 patients were given from 15 to $30 \mathrm{mg} / \mathrm{d}$ (mean 24.2) (subgroup 2). Seventy eight patients, 30 men and 48 women, were diagnosed as having TA, pure or initially associated with PMR (group B). In this group 25 patients were given a starting dose of prednisone ranging from 10

Table 1 Comparison of outcome for patients diagnosed as having pure TA and those diagnosed as having mixed $T A / P M R$

\begin{tabular}{|c|c|c|}
\hline & $\begin{array}{l}\text { Pure TA } \\
(n=38)\end{array}$ & $\begin{array}{l}\text { Mixed } \\
T A / P M R \\
(n=40)\end{array}$ \\
\hline Men/women (n) & $15 / 23$ & $15 / 25^{* *}$ \\
\hline \multicolumn{3}{|l|}{ Positive temporal artery } \\
\hline Age (years) & $75 \cdot 4(7 \cdot 1) \dagger$ & $76 \cdot 8(7 \cdot 5)^{*}$ \\
\hline $\operatorname{ESR}(\mathrm{mm} / 1 \mathrm{st} \mathrm{h})$ & $107 \cdot 2(27 \cdot 3)$ & $101.9(24.8)^{*}$ \\
\hline Prednisone starting dose & $39.7(18 \cdot 5)$ & $36.6(15 \cdot 8)^{*}$ \\
\hline \multirow{2}{*}{\multicolumn{3}{|c|}{$\begin{array}{l}\text { Duration of treatment } \\
\text { (months) } \ddagger \\
\text { Number of patients who } \\
\text { experienced: }\end{array}$}} \\
\hline & & \\
\hline treatment withdrawal & 19 & $21^{* *}$ \\
\hline $\begin{array}{l}\text { relapse } \\
\text { visual or neurological }\end{array}$ & 11 & $10^{* *}$ \\
\hline complications of TA & 8 & $7^{* *}$ \\
\hline
\end{tabular}

${ }^{*} \mathrm{p}>0.05$ (Student's $t$ test); ${ }^{* *} \mathrm{p}>0.05\left(\chi^{2}\right.$ test).

+Values are mean (SEM).

$\ddagger$ Concerns patients who achieved treatment withdrawal. to $20 \mathrm{mg} / \mathrm{d}$ (mean 16.2) (subgroup I), 28 patients were given over 20 and under $60 \mathrm{mg} / \mathrm{d}$ (mean 39.1) (subgroup II), 25 patients were given from 60 to 90 $\mathrm{mg} / \mathrm{d}$ (mean 66.0) (subgroup III).

GROUP A

Table 2 gives the results for the whole group.

Temporal artery biopsy was performed on 56 patients. The evolution of PMR was not significantly different in the eight patients with positive temporal artery biopsy and the 48 patients with negative biopsy (Table 3).

Table 3 Comparison of outcome in patients with PMR and a positive or negative temporal artery biopsy

\begin{tabular}{|c|c|c|}
\hline & $\begin{array}{l}\text { Positive } \\
\text { biopsy } \\
(n=8)\end{array}$ & $\begin{array}{l}\text { Negative } \\
\text { biopsy } \\
(n=48)\end{array}$ \\
\hline Men/women (n) & $2 / 6$ & $8 / 40^{* *}$ \\
\hline Age (years) & $75 \cdot 1(6 \cdot 8) \dagger$ & $71 \cdot 2(8 \cdot 7)^{*}$ \\
\hline $\operatorname{ESR}(\mathrm{mm} / 1 \mathrm{st} \mathrm{h})$ & $75 \cdot 1(6 \cdot 0)$ & $77.8(33 \cdot 2)^{*}$ \\
\hline $\begin{array}{l}\text { Prednisone starting dose } \\
(\mathrm{mg} / \mathrm{d})\end{array}$ & $14 \cdot 1(5 \cdot 2)$ & $14 \cdot 3(6 \cdot 3)^{*}$ \\
\hline $\begin{array}{l}\text { Duration of treatment } \\
\text { (months) } \ddagger\end{array}$ & $25 \cdot 5(12 \cdot 8)$ & $25 \cdot 1(10 \cdot 1)^{*}$ \\
\hline $\begin{array}{l}\text { Patients (No,\%) who } \\
\text { experienced: }\end{array}$ & & \\
\hline treatment withdrawal & 4,50 & $22,46^{* *}$ \\
\hline relapse & 1,13 & 5,10 \\
\hline further symptoms of TA & 0,0 & 4,8 \\
\hline
\end{tabular}

${ }^{*} \mathrm{p}>0.05$ (Student's $t$ test); ${ }^{* *} \mathrm{p}>0.05$ ( $\chi^{2}$ test, Yates's correction). †Values are mean (SEM).

$\ddagger$ Concerns patients who achieved treatment withdrawal.

Table 2 Comparison of patients diagnosed as having pure PMR (group A) and those diagnosed as having TA (group B)

\begin{tabular}{|c|c|c|c|}
\hline & $\begin{array}{l}\text { Group } A \\
(n=132)\end{array}$ & $\underset{(n=78)}{\text { Group }} B$ & p Value \\
\hline \multicolumn{4}{|l|}{ Positive temporal artery } \\
\hline biopsy (No.\%) & $8 / 56,14$ & $60 / 78,77$ & $<0.001$ \\
\hline Age (years) & $71.6(8.9) \dagger$ & $76 \cdot 1(7 \cdot 4)$ & $\mathbf{N S}^{*}$ \\
\hline $\operatorname{ESR}(\mathrm{mm} / 1 \mathrm{st} \mathrm{h})$ & $75.6(30 \cdot 8)$ & $104.5(26 \cdot 4)$ & $<0.001$ \\
\hline \multicolumn{4}{|l|}{ Prednisone starting dose } \\
\hline$(\mathrm{mg} / \mathrm{d})$ & $13.9(5.6)$ & $38 \cdot 1(17 \cdot 4)$ & $<0.01$ \\
\hline $\begin{array}{l}\text { Duration of treatment } \\
\text { (months) } \ddagger\end{array}$ & $25 \cdot 7(11 \cdot 9)$ & $30.9(14.0)$ & NS $^{*}$ \\
\hline \multicolumn{4}{|l|}{$\begin{array}{l}\text { Patients (No, \%) who } \\
\text { experienced: }\end{array}$} \\
\hline treatment withdrawal & 65,49 & 40,51 & NS \\
\hline relapse & 16,12 & 21,27 & $<0.01$ \\
\hline $\begin{array}{l}\text { steroid related adverse effects } \\
\text { visual or neurological }\end{array}$ & 10,8 & 41,53 & $<0.001$ \\
\hline complications of TA & 0,0 & 15,19 & $<0.001$ \\
\hline
\end{tabular}

${ }^{*} \mathrm{NS}=\mathrm{p}>0 \cdot 05$ (Student's $t$ test).

†Values are mean (SEM).

¥Concerns patients who achieved treatment withdrawal: 65 in group $A$ and 40 in group $B$. 
Subgroups 1 and 2 were comparable for mean age, sex ratio, mean ESR, results of temporal artery biopsy. No significant difference was noticed between these two subgroups as regards the following follow up data: percentage of patients who experienced treatment withdrawal, relapse, further development of TA symptoms, and mean duration of CS treatment. The percentage of patients who experienced CS related adverse effects, however, was significantly higher in subgroup $2(21 \%)$ than in subgroup $1(3 \%)(p<0 \cdot 01)$ (Table 4$)$. Sixty five patients achieved treatment withdrawal after a mean duration of 25.7 (SEM 11.9) months. The mean observation period after the withdrawal of CS treatment was $43.2(21.5)$ months. Sixty seven patients were still receiving $\mathrm{CS}$ at the time of this study; their mean duration of continuing treatment was $16 \cdot 2(12.4)$ months and their mean dosage of prednisone at the time of the study was $4 \cdot 1(1 \cdot 8)$ $\mathrm{mg} / \mathrm{d}$. Only nine patients with initially pure PMR subsequently developed clinical symptoms of TA, a mean 14.6 (9.4) months after the onset of PMR. A comparison of the nine patients who later developed clinical symptoms of TA and the 123 who did not showed no predictive feature that such a development would take place. In particular, none of the nine patients with further evidence of TA had a positive temporal artery biopsy at initial presentation with pure PMR (when the biopsy had been performed). None of the 132 patients with clinically pure PMR experienced visual or neurological complications of TA.

\section{G R O U P B}

Table 2 gives the results for the whole group. Temporal artery biopsy was performed on all 78 patients and was positive in 60. Abnormalities on physical examination of temporal arteries were more prevalent in patients with positive biopsy $(46 / 60)$ than in patients with negative biopsy $(8 / 18)$ $(p<0 \cdot 01)$. No significant difference on follow up was observed between the patients with positive anc those with negative temporal artery biopsy.

Subgroups I, II, and III were comparable fop mean age, sex ratio, mean ESR, results of tempora $\$$ artery biopsy, percentage of patients with headache음 jaw claudication, general symptoms, associate of symptoms of PMR, physical abnormalities of temฉ poral arteries, and positive biopsy. But the presenct in subgroup III of all 12 patients with initial visuaL symptoms made the three subgroups non? homogeneous.

No significant difference was observed betweer the three subgroups for the following follow up data percentage of patients who experienced treatments withdrawal, relapse, further TA complications, and mean duration of treatment. The percentage of patients who experienced CS related adverse effects, however, was higher as the starting dosage of CS increased $(p<0.001)$ (Table 5). Table 6 details all the $\mathrm{CS}$ related adverse effects. Complications of CS treatment leading to death (one systemic sepsis?

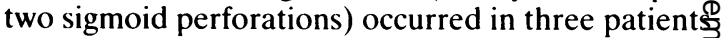
out of the 53 patients treated with the highese dosages of CS (subgroups II and III). Forty patients achieved treatment withdrawal after a mean duga tion of $30.9(14.0)$ months. The mean observation period after the withdrawal of CS treatment $32.8(17.9)$ months. Thirty eight patients were stils receiving CS at the time of this study; their mear duration of continuing treatment was $30 \cdot 1(23.5 \mathrm{D}$ months and their mean dosage of prednisone at the time of the study was $9 \cdot 5(2 \cdot 1) \mathrm{mg} / \mathrm{d}$. Fifteen patient experienced TA complications: these complications were present at initial presentation in 12 patients? and all of them were treated with starting doses of prednisone of at least $60 \mathrm{mg} / \mathrm{d}$. For these 12 patient complications were as follows: (a) three patients experienced further complications of TA despite high doses of CS (one patient with initial loss of

Table 4 Comparison of patients with initially pure PMR (group A) treated with a prednisone starting dose of 7-12 mg/d (subgroup 1) and those treated with 15-30 mg/d (subgroup 2)

\begin{tabular}{|c|c|c|c|}
\hline & $\begin{array}{l}\text { Subgroup } 1 \\
(n=98)\end{array}$ & $\begin{array}{l}\text { Subgroup } 2 \\
(n=34)\end{array}$ & p Value \\
\hline $\begin{array}{l}\text { Duration of treatment } \\
\text { (months) } \dagger\end{array}$ & $25 \cdot 0(11 \cdot 2) \ddagger$ & $28 \cdot 1(13 \cdot 3)$ & NS* \\
\hline $\begin{array}{l}\text { Patients (No,\%) who experienced: } \\
\text { remission } \\
\text { relapse } \\
\text { further symptoms of TA } \\
\text { corticosteroid related adverse effects }\end{array}$ & $\begin{array}{c}50,51 \\
13,13 \\
7,7 \\
3,3\end{array}$ & $\begin{array}{c}15,44 \\
3,9 \\
2,6 \\
7,21\end{array}$ & $\begin{array}{l}\text { NS** } \\
\text { NS** } \\
\text { NS** } \\
<0 \cdot 01\end{array}$ \\
\hline \multicolumn{4}{|c|}{$\begin{array}{l}{ }^{*} \mathrm{NS}=\mathrm{p}>0.05 \text { (Student's } t \text { test); }{ }^{* *} \mathrm{NS}=\mathrm{p}>0.05\left(\chi^{2} \text { test, Yates's correction). }\right. \\
\text { †Concerns patients who achieved treatment withdrawal. } \\
\ddagger \text { Values are mean (SEM). }\end{array}$} \\
\hline
\end{tabular}


vision of one eye developed contralateral blindness and hemiplegia, one patient with initial diplopia developed hemiplegia, and one patient with initial diplopia died of intracranial arteritis, proved at necropsy). (b) Two patients with initial loss of vision of one eye did not recover normal vision but did not experience further complications. (c) Seven patients (four with initial diplopia and three with blurred

Table 5 Comparison of patients with TA (group B) treated with a prednisone starting dose of 10-20 mg/d (subgroup I), over 20 and under $60 \mathrm{mg} / \mathrm{d}$ (subgroup II), and 60-90 mg/d (subgroup III)

\begin{tabular}{lllll}
\hline & $\begin{array}{l}\text { Subgroup I } \\
(n=25)\end{array}$ & $\begin{array}{l}\text { Subgroup II } \\
(n=28)\end{array}$ & $\begin{array}{l}\text { Subgroup III } \\
(n=25)\end{array}$ & p Value \\
\hline $\begin{array}{l}\text { Duration of treatment (months)* } \\
\begin{array}{l}\text { Patients (No,\%) who experienced: } \\
\text { remission }\end{array}\end{array}$ & $28 \cdot 4(12 \cdot 5) \dagger$ & $34 \cdot 4(15 \cdot 8)$ & $29 \cdot 3(12 \cdot 9)$ & NS \\
$\begin{array}{l}\text { relapse } \\
\text { visual or neurological complications } \\
\text { of TA (once treatment started) }\end{array}$ & 14,56 & 15,54 & 11,44 & $\mathrm{NS}$ \\
corticosteroid related adverse effects & 8,32 & 8.29 & 5,20 & $\mathrm{NS}$ \\
\hline
\end{tabular}

*Concerns patients who achieved treatment withdrawal.

†Values are mean (SEM).

Table 6 Possible complications of corticosteroid treatment in patients with TA (group B)

\begin{tabular}{|c|c|c|c|c|}
\hline & Subgroup $I^{*}$ & Subgroup $I^{*}$ & Subgroup $I I I^{*}$ & Total \\
\hline $\begin{array}{l}\text { Number of patients who developed } \\
\text { corticosteroid related adverse effects }\end{array}$ & $3 / 25$ & $16 / 28$ & $22 / 25$ & $41 / 78$ \\
\hline Symptomatic vertebral osteoporosis & 2 & 7 & 15 & 24 \\
\hline Fractured femur & 0 & 1 & 2 & 3 \\
\hline Ischaemic necrosis of hip & 0 & 0 & 2 & 2 \\
\hline Increased blood pressure & 2 & 5 & 6 & 13 \\
\hline Diabetes & 1 & 2 & 4 & 7 \\
\hline Cushingoid features & 0 & 2 & 7 & 9 \\
\hline Steroid myopathy & 0 & 1 & 2 & 3 \\
\hline Complicated ulcer disease & 0 & 2 & 4 & 6 \\
\hline Sigmoid perforation & 0 & $1 \dagger$ & $1 \dagger$ & 2 \\
\hline Systemic sepsis & 0 & $1 \dagger$ & 0 & 1 \\
\hline Tuberculosis & 0 & 0 & 1 & 1 \\
\hline Herpes zoster & 0 & 1 & 0 & 1 \\
\hline Cataracts & 0 & 1 & 1 & 2 \\
\hline Glaucoma & 0 & 1 & 0 & 1 \\
\hline Total (No,\%) & 5,7 & 25,33 & 45,60 & 75,100 \\
\hline
\end{tabular}

*Prednisone starting doses were $10-20 \mathrm{mg} / \mathrm{d}$ in subgroup I, over 20 and under $60 \mathrm{mg} / \mathrm{d}$ in subgroup II, and $60-90 \mathrm{mg} / \mathrm{d}$ in subgroup III. †Death.

Table 7 Comparison of patients with TA who developed complications and those who did not

\begin{tabular}{|c|c|c|c|}
\hline & $\begin{array}{l}T A \text { with } \\
\text { complications } \\
(n=15)\end{array}$ & $\begin{array}{l}\text { TA without } \\
\text { complications } \\
(n=63)\end{array}$ & p Value \\
\hline $\begin{array}{l}\text { Male sex }(\text { No,\%) } \\
\text { Patients }(\text { No,\%) with: }\end{array}$ & 10,67 & 20,32 & $<0.02$ \\
\hline headache & 13,87 & 56,89 & NS** \\
\hline jaw claudication & 8,53 & 20,32 & $\mathrm{NS}^{* *}$ \\
\hline general symptoms & 10,67 & 45,71 & NS ${ }^{* *}$ \\
\hline associated symptoms of PMR & 8,53 & 32,51 & NS $* *$ \\
\hline positive temporal artery biopsy & 12,80 & 48,76 & NS** \\
\hline Age (years) & $73.6(6 \cdot 4) \dagger$ & $76.7(7 \cdot 5)$ & $\mathrm{NS}^{*}$ \\
\hline ESR (mm/1st h) & $100 \cdot 5(19.4)$ & $105 \cdot 5(27 \cdot 4)$ & NS* \\
\hline
\end{tabular}

${ }^{*} \mathrm{NS}=\mathrm{p}>0.05$ (Student's $t$ test); ${ }^{* *} \mathrm{NS}=\mathrm{p}>0.05\left(\chi^{2}\right.$ test $)$.

+Values are mean (SEM). 
vision) recovered normal vision. Three of the 66 patients without TA complication at initial presentation developed complications within three months of starting CS treatment: one patient from subgroup I, who against advice stopped taking $20 \mathrm{mg} / \mathrm{d}$ of prednisone (though it had provided dramatic improvement), died of intracranial arteritis, proved at necropsy, one patient from subgroup II experienced loss of vision of one eye (a starting dose of $30 \mathrm{mg} / \mathrm{d}$ prednisone had been ineffective and had been promptly increased to $60 \mathrm{mg} / \mathrm{d}$; the disease had then appeared to be controlled), and one patient from subgroup III developed hemiplegia (treatment with $60 \mathrm{mg} / \mathrm{d}$ of prednisone had at first seemed to be effective). A comparison of the 15 patients who developed TA complications (at initial presentation or once CS treatment started) showed that men developed these complications significantly more frequently than women $(p<0 \cdot 02)$ (Table 7$)$.

\section{Discussion}

Our results suggest that $(a)$ on the basis of the clinical symptoms at initial presentation, and regardless of temporal artery biopsy findings, a clear distinction can be made between a benign disease, PMR, and a more serious one, TA; $(b)$ men seem at risk of experiencing TA complications more than women; $(c)$ whether high doses of CS are useful for the treatment of all cases of TA is uncertain. High doses are of no use whatsoever for the treatment of clinically pure PMR.

If PMR and TA are two expressions of a single disease then patients with PMR might be at risk of experiencing visual complications. We observed that visual or neurological complications were experienced by $15 / 78(19 \%)$ of our patients with TA, comparable with results of other reports, ${ }^{10} 11$ while none of our 132 patients with pure PMR experienced complications of this kind. Although Jones and Hazleman reported a high complication rate in PMR, ${ }^{12}$ most authors have emphasised the absence of complications in pure PMR. ${ }^{1314}$ The difference in prognosis for pure PMR and TA makes it necessary to maintain a clear separation between these two diseases.

Does a patient with pure PMR and histological evidence of giant cell arteritis on temporal artery biopsy have to be regarded as having TA for prognosis and treatment? We did not notice any significant difference during the course of the disease in patients with pure PMR between those with a positive temporal artery biopsy and those with a negative biopsy. As previously reported temporal artery biopsy did not seem to have any prognostic value in PMR. ${ }^{8} 12$ A positive temporal

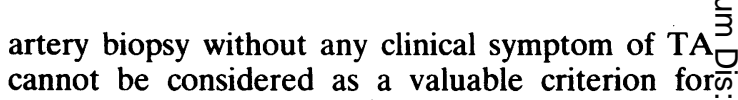
inclusion of a patient with pure PMR into the TA $\Rightarrow$ group and should not be taken into account. Neither? did we observe any significant difference during the? course of the disease in patients with TA between those with a positive temporal artery biopsy anf those with a negative biopsy. We thus agree with Vilaseca et al, who judged that there was no point in performing a temporal artery biopsy on patientswith pure PMR and on those with clinically certain TA as its results did not influence prognosis and treatment. ${ }^{15}$ Its only use is to establish a clinically uncertain diagnosis in few atypical cases of TA, and for pure nosological purposes. An analysis of the clinical symptoms at initial presentation appears tọ be the most accurate method of distinguishing between pure PMR and TA.

What starting dosage of CS should be used ancB how long should the patients with PMR and TA be treated?

Some authors recommend prednisone starting $\frac{\mathbb{D}}{0}$ doses of over $30 \mathrm{mg}$ daily, ${ }^{2-4}$ while others consideE that doses of under $15 \mathrm{mg}$ daily are adequate treatment for PMR. ${ }^{6-8} 14$ A few authors haye suggested that there is no evidence that CS for better than non-steroidal anti-inflammatory drugs for treatment of PMR. ${ }^{16} 17$ but there has never berp a double blind controlled trial of the two methods All our patients, therefore, were treated with CS as this dramatically improved their condition. WE found that prednisone starting doses of over $15 \mathrm{mg} / \mathbb{B}$ significantly increased the number of $\mathrm{CS}$ relate 5 adverse effects $(p<0 \cdot 01)$ without providing any benefit. Our results (mean duration of treatment number of patients who experienced relapse op further symptoms of TA) were comparable with those previously reported. ${ }^{814}$ A starting dose o $\overline{\hat{p}}$ $10-15 \mathrm{mg}$ daily of prednisone and a slow decrease og CS dosage, allowing a withdrawal of the treatment about two years later, seems an adequate treatmen? schedule for pure PMR, and causes very few adverse effects. The generally agreed starting dose of prednisone for treatment of TA ranges from 30 to $6 \%$ $\mathrm{mg}$ daily as it has been considered that high doses. of CS prevent visual and neurological compliN cations. ${ }^{18} 19$ A few authors suggested that loweh doses could be adequate in some cases. ${ }^{6}$ W showed that 25 patients treated with $10-20 \mathrm{mg} / \mathrm{d}$ of prednisone did not experience more TA complica? tions and had significantly less CS related advers $\$$ effects $(p<0.001)$ than 53 patients treated wit| higher doses. The absence of randomised allocation ${ }^{+}$ of CS dosages may have been responsible for an important bias. Furthermore, the presence of all the्ष patients with initial visual symptoms in the group oक 
25 patients treated with the highest dosages has made the groups non-homogeneous (these patients were probably affected with a more severe disease). Nevertheless, high doses were not completely preventative against TA complications as five patients developed such complications despite high starting doses of CS. Similar events had been reported previously. ${ }^{20}$ Two different categories seem to exist in the TA group. The first category consists of patients who can be adequately treated with low doses of CS, i.e., a starting dose of prednisone of no more than $20 \mathrm{mg} / \mathrm{d}$ : higher doses increase the rate of adverse effects without providing any benefit; a slow decrease of CS dosage usually allows a withdrawal of the treatment two to three years later. The second category consists of patients affected with a more severe form of TA, in whom even high doses of CS are not always effective in preventing complications. The difficulty in recognising this second category is worrying. We found that men were more likely to experience TA complications than women $(p<0 \cdot 02)$. This worse prognosis attached to the male sex in TA has not been previously reported and needs to be confirmed.

The fear that PMR may be an underlying form of TA and the idea that high doses of CS ensured the best prevention against TA complications has led to a probably unjustified increase of CS dosage for treatment of both PMR and TA. This overtreatment is certainly harmful, especially in elderly people. Our study supports the idea that CS dosage can be reduced, but allowance must be made for its retrospective character. Until now, the starting dosage and the duration of CS treatment for PMR and TA were empirically determined. Controlled trials are needed to evaluate the results of low dosages of CS treatment for both PMR and TA.

\footnotetext{
References

1 Hamrin B. Polymyalgia arteritica. Acta Med Scand /Suppl] 1972; 533: 1-131.

2 Sørensen P S, Lorenzen I. Giant cell arteritis, temporal arteritis
}

and polymyalgia rheumatica. Acta Med Scand 1977: 201: 207-13.

3 Bengtsson B A. Malmvall B E. Prognosis of giant cell arteritis including temporal arteritis and polymyalgia rheumatica. Acta Med Scand 1981; 209: 337-45.

4 Fauchald P. Rygvold O, Øystese B. Temporal arteritis and polymyalgia rheumatica: clinical and biopsy findings. $A n n$ Intern Med 1972: 77: 845-52.

5 Goodman B W. Temporal arteritis. Am J Med 1979: 67: 839-52.

6 Myles A B. Polymyalgia rheumatica and giant cell arteritis: a seven-year survey. Rheumatology and Rehabilitation 1975: 14: 231-5.

7 Spicra H. Davison S. Long term follow-up of polymyalgia rheumatica. Mt Sinai J Med (NY) 1978; 45: 225-9.

8 Behn A R. Pcrera T, Myles A B. Polymyalgia rheumatica and corticosteroids: how much for how long? Ann Rheum Dis 1983; 42: 374-8.

9 Paolaggi J B. Chaouat D. Barres D. Hoffman N. Auquier L. Etude des variations comparées de la vitesse de sédimentation. de l'haptoglobine et de l'orosomucoide au cours de l'évolution des pseudopolyarthrites rhizoméliques et des artérites temporales. Semaine des Hopitaux de Paris 1983: 59: 523-8.

10 Huston K A. Hunder G G. Lie J T. Kennedy R H. Elveback L R. Temporal arteritis. A 25-year epidemiologic, clinical and pathological study. Ann Intern Med 1978; 88: 162-7.

11 Godeau P. Aubert L. Guillevin L. Aspect clinique, évolution et pronostic de la maladie de Horton. Ann Med Interne (Paris) 1982; 133: $393-400$.

12 Jones J G. Hazleman B L. Prognosis and management of polymyalgia rheumatica. Ann Rheum Dis 1981; 40: 1-5.

13 Spiera H, Davison S. Treatment of polymyalgia rheumatica. Arthritis Rheum 1982: 25: 120.

14 Ayoub W T, Franklin C M. Torretti D. Polymyalgia rheumatica. Duration of therapy and long term outcome. Am J Med 1985: 79: 309-15.

15 Vilaseca J, Gonzáles A, Cid M C, Lopez-Vivancos J, Ortega A. Clinical usefulness of temporal artery biopsy. Ann Rheum Dis 1987; 46: 282-5.

16 Chuang T, Hunder G G, Ilstrup D M. Kurland L T. Polymyalgia rheumatica. A 10-year epidemiologic and clinical study. Ann Intern Med 1982; 97: 672-80.

17 David-Chausse J, Dehais J, Leman A. Résultats d'une enquête régionale sur le traitement de la pseudopolyarthrite rhizomélique et de l'artérite temporale. Rev Rhum Mal Osteoartic 1983; 50: $563-71$

18 Meadows S P. Giant cell arteritis and blindness. Br J Hosp Med 1967: 1: $835-40$

19 Hollenhorst R W, Brown J R, Wagener H, Shick R M. Neurologic aspects of temporal arteritis. Neurology 1960; 10: 490-8.

20 Rosenfeld S I, Komorsky G S, Klingele T G, Burde R M. Cohn E M. Treatment of temporal arteritis with ocular involvement. Am J Med 1986; 80: 143-5. 